\title{
CHANGING PRESENTATION STYLES OF KATHAK IN ITS JOURNEY FROM TEMPLE TO THE PROSCENIUM
}

\author{
Mansi Saxena
}

Research Scholar, Department of Dance. Punjabi University Patiala

\section{Introduction}

From the past 500 years, Kathak has been firmly established as a Classical Dance form. Because it is Classical, it follows certain rules and regulations as laid down by Natyashastra and Abhinaya Darpan as well the eminent Gurus of the arts.

- It contains all the Abhinaya i.e. Angika, Vachika, Aharya and Satvika.

- If follows the Hindustani School of classical Music.

- Presentation of Kathak includes three Aspects. Natya, Nritta and Nritya.

As mentioned above, style of presentation of Kathak includes Natya, Nritta and Nritya. Nritta refers to the pure technical part of Kathak, Natya includes its Abhinaya portion while Nritya Ang of Kathak lays stress on the balanced presentation of both technical as well as the Abhinaya portion of Kathak and thus is a combination of Nritta and Natya both.

Under the influence of the changing Socio-Political environment of different Historical Eras, the Presentation Style of Kathak has faced numerous alterations. While Natya Ang of Kathak got established in the Vedic era as well as the Buddha period following the solo presentation format, the Nitta aspect was highlighted in Mughal era followed by the popularization of the group presentations in the Modern era. Movement and poses used in the Technical format of Kathak also got modified with the changing times.

Hence, we can say that during the journey of Kathak from the Temples to the Proscenium theatre, its Style of Presentation faced numerous changes owing to the demand or needs of the Masters or the Socio-Political and the religious environment prevalent in the respective times and thus contributed in evolving the classical dance as a refined art form of the Modern world. Changes in the Presentation Style of Kathak can be witnessed by turning the pages of History.

\section{Natya Aspect i.e. Story Telling Format of Kathak}

The Natya form of Kathak popularized in the Vedic era reference of which are available in number of Literary sources: One of the verses in Adiparva of the epic Mahabharata States-[Shovana Narayan, 2004]

Kathakscapre rajan'Sravanasca" Divya hyanani Ye Capi Vanaukasah pathanimadhuram durjaha”.e. it gives information about the profession of Kathak i.e. they were a group of Brahmins who recieted tales of Gods and Goddesses using mimes and songs.

In the epic Ramayana, rhapsodists\& recitors are mentioned who specialized in the art of storytelling. They were the 2 sons of Lord Rama, Lav \& Kusha who rendered the Ramayana reciting with facial expression \&body gestures. 
Above references reflect that the Presentation style of the Art form in those times followed the story recitation format also that the performers of the period were both dancers and actors. Hence, it may be assumed that the Natya element of Kathak i.e the mimetic concept of story telling accompanied by body movements and facial expressions got established as the Presentation Style of Kathak in the Vedic Era.

\section{Addition of Footwork and Nritta Ang in the Natya Aspect of Kathak}

Addition of Nritta Ang to the story telling Format of Kathak took place in the period of Lord Buddha which may be considered from $2^{\text {nd }}$ century B.C to $9^{\text {th }}$ century A.D.. The Great war of Mahabharata led to widespread destruction. During this period, there was spurt in the temple building activities.

Temples with walls, stupas etc. embellished with the dancing figures and poses of various divinities which not only are found to have similarities with the classical dance form , Kathak, but also throw light on the style of presentation of Kathak during the Period.

"The figures of Yakshis" and apsaras from Patiputra, Bharhut,Sanchi, Kausabi, Mathura Jhansi, Bodh Gaya \& Deoghar indicate dance movements practiced in the region. Some of the recesses in the ruins of Nalanda show dancing "apsaras" in Poses similar to the ones used in Kathak."(Shovana Narayan-2005)

"The temples of Raja Rani of Parasuramesvara and of Lingraja, all reverberate with music and dance. Looked at it closely, one is impressed by the fact that the sculptor was not only a keen observer of movement, but was also a self- conscious illustrator of the basic position i.e. sthanakas \& fundamental movements like Chari described in the Natyashastra. (Kapila Vatsyayan,1965)

From the above, it may be assumed that dance prevalent in the era was similar to that of Kathak. Since the dance poses in temples were inscribed with basic movements like the Chari, sthanakas etc. ,the dance form, Kathak in that period, might have been technically composed of these fundamental movements and also based on the tenants of Natyashastra.

Evidences of the Presentation Style of Kathak ${ }^{4}$ dance form can also be gathered from the extent works of Sanskrit literature.

"Panini in siddhanta kaumudi lays down the sutra- Kathadibhyashthak from which the word 'Kathak' is derived and is translated as the one who is well versed in story telling."(Dr. Bharti Gupta 2004)

Thus, all above references prove that Kathak dance prevalent during this period was performed solo following the story telling format. Technique of the Dance form was based on the aspects of Natyashastra and style of Presentation include movements like Chari, Sthanaka which portrays the addition of the Nritta ang of Kathak to the already existing mimetic story telling format of the Vedic times. 


\section{Golden Period for the Development of the Nritta Ang of Kathak in the Mughal Era}

During the establishment of the Mughal Rule, Kathak shifted from the temple to the courts of Nawabs and no longer followed the story telling format. The classical dance of North no longer remained an aspect of temple rituals which helped it in developing into a relatively flexible classical dance style and it emerged as a masterful blend of the best in Hindu and Islamic aesthetics.

The Folk elements of Rasa Leela became a part of the repertoire of Kathak "Rasa Leela werw" refined folk form of Radha Krishna Dance accompanied by devotional songs \& Keertans as that described the poses and Dance movements of Krishna. The gestures , whirling movements, pauses and rhythmic syllables in text i.e. Kavit were primary folk elements that developed into an elaborate classical form in Kathak dance." [ Ragini Devi,1972]

From above, it may be assumed that primary folk elements of Rasa Leela like the whirling movements and the Nritya Ang like Kavit got incorporated into the presentation of Kathak.

Kathak received a new impetus and arrived at a recognizable point of excellence with the coming of the benign rule of the Mughal Emperor- Akbar. Kathak then depicted less of original legends of Lords \& became more rhythm oriented. Technique of Kathak incorporated in it rhythmic compositions like Tarana, adana, farmaishi bols with patterns based on moods of nature, sounds of instruments, animation like ashwa paran,primalu etc. New musical forms like thumri, dadra ghazal also became a part of the repertoire of music used in Kathak.Also, Kathak saw great efflorescence in the $19^{\text {th }}$ century during the reign of Nawab Wajid Ali Shah, last Nawab of Awadh. Gat and paltas are said to be the contribution of Wajid Ali Shah $\left(18 \& 19^{\text {th }}\right.$ century $)$. He also encouraged expressional interpretation of Thumri, Dadra and Ghazals.

Thus, it can be said that along with performing Abhinaya on the Poetry of the Sufi Saints and Ashtchap Poets as well as on Musical pieces like Dadra, Hori and Thumri, the Nritta anga of Kathak including Tora, Tukra etc. got incorporated in the Format of Presentation of Kathak..

\section{Courtesan Style of Presentation of the Nautch Girls in the British period}

On the eve of the reinstatement of the art of dance in India in the $2^{\text {nd }}$ quarter of the present century, there was a $2^{\text {nd }}$ Global Impact on Kathak due to the coming of the British rule in India. The form got shifted from its original purpose of devotion and found place in the Chambers of Tawaifs or prostitute dancers who came to be known as the Nautch girls during those times. Style of Presentation of Kathak used by these Nautch Girls is discussed by some of the Britishers:

"Charles Doyley in his book, The European in India, published in 1813, gives the following account of a dancing woman of Lucknow. ' The dancing ${ }^{7}$ women of India have no variety of steps, the feet kept close and parallel, one foot advancing a few inches 
and other foot following it; is however done with remarkable exactness as to times which, on all occasions, is regulated by instruments played by men.(Projesh Banerji, 1982 )

Form the above lines, it may be assumed that presentation style of Kathak in the British period was very graceful and was full of expressions. However, there were lesser variety of steps performed with high degree of exactness and perfection Thus, we can say that Delicate Aspects of Kathak developed in the Presentation style of the art form

\section{Impact of Technology and Fusion of Culture on the Style of Presentation of} Kathak in the Modern World

Mutations are observed in the style of Presentation of Kathak in the Modern Period. Demand of time has led to the Presentation of Kathak at a faster tempo.

" The Proscenium ${ }^{8}$ distance between performer and audience has resulted in erasing the subtleties of an eyebrow, wrist movement or torso genuflection. Today's mind and not particularly well informed audience mistakes clearly rehearsed rhythmic razzmatazz for improved brilliance. In the Present day, Delicate aspects like That and Gat have become minimal in the vertigo of speed and virtuosity" [Leela Venkataraman,2002].

Various experiments have also been done in the field of Kathak presenting it with other dance forms by the masters of the Art. For eg:- Pt. Rajendra Gangani did a Jugalbandi with a Mohiniattam dancer, Dr. Deepti Bhalla in 1995 while Shovana Narayan composed an item "Tridhara" combining Bharatnatyan and Odissi with Kathak.

Few artists have even successfully tried to incorporate Elements of Martial arts, Chhau and Kalaripayatu as well as Non-Indian dance forms like Flamenco and Western classical Ballet in their compositions. Apart from all the above, various choreographic patterns have been tried in the Kathak compositions for eg:- Kumudini Lakhia added a new texture to the rhythm by dividing a technical piece of Kathak i.e. Tihai among 3 dancers in "Dhabkar".

"These efforts indicate the ${ }^{9}$ determination with which issues and concerns as a result of Globalization, Muti-Culturism, technogical advancements, change in aspiration and desires, have been addressed by the artists. They clearly send a message that the art form is ever pulsating, vibrant and forward looking. The strides made by the practitioners have enriched the dance tradition of this sub-continent, keeping intact the spirit and flavour of the 2000 year old dance from"[Shovana Narayan,2004]

Thus, Presentation style of Kathak underwent number of Changes in the Modern era as described above under the Impact of Globalization of the world.

\section{Conclusion}

Concluding the work, we can say that changes have taken place in the Style of Presentation of Kathak, throughout the different historical epochs . These changes or Innovation in one time have now become a part of the Tradition today. 
"The inner quest for creativity by the Kathak artists has ${ }^{1}$ added new dimensions at various points which may have been the Path breakers and Innovation at that point of time, but due to vast acceptance, have now become part of Tradition today "[Reginald Massey,2004]

Thus, such Innovations in the Style of Presentation of Kathak have not only brought a change in the format of the art but also have helped in the enrichment of the classical dance thus presenting it as a highly sophisticated and polished art form on the Global Platform.

\section{End Notes}

1. Shovana Narayan- Kathak - Rhythmic Echoes

2. Shovana Narayan- Indian Classical Dance

3. Kapila Vatsyayan - The Dance in India

4. Dr. Bharti Gupta- Kathak Sagar

5. Ragini Devi- Dance Dielects of India

6. Projesh Banerji - Kathak Dance through the Ages

7. Leela Venkatraman- Indian Classical Dance- Tradition in transition

8. Shovana Narayan- Kathak- Rhythmic Echoes

9. Reginald Massey- India's Dances- Their History, Technique \& Repertoire

\footnotetext{
Reginald Massey- India's
} 